\title{
Talking to water: Memory, gender and environment for Hazara refugees in Australia
}

\author{
HEATHER GOODALL AND LATIFA HEKMAT \\ University of Technology Sydney
}

\begin{abstract}
'It gives me peace of mind when I talk to water'-A Hazara woman and refugee, now living in Sydney
\end{abstract}

\section{Abstract}

This article explores the life histories of 12 Hazara women in south-eastern Australia, each of whom arrived from 2005 onwards. It traces the environmental dimensions of their experiences of home, flight and new settlement, with a sustained focus on how water played a role in their journeys. There has been little discussion to date about the gendered relationships to place and environments for refugees, nor on how the well-publicised depictions of refugee journeys are often gendered, although seldom recognised as such. During in-depth oral history interviews, these Hazara refugee women talked about 'home' and 'water', depicting them as entwined concepts in their recollected early lives in Afghanistan, their long, enforced residence in transit ghettos and their new experiences in south-eastern Australia. The 'everyday' and material experiences they recall and narrate about 'homes' and 'water' in each of these locations of their past and present point not only to the environmental context and implications of their experiences but to the processes of mourning that accompany such traumatic journeys.

Keywords: migration, environmental dislocation, identity, gender, Hazara refugees

\section{Introduction}

Seeking refuge is a long and often terrifying process. It is always gendered. Women and men face very different experiences, vulnerabilities and dangers as they flee intolerable conditions of war or persecution, crossing borders in the hope of finding protection. This has involved long physical journeys - across many landscapesforcing refugees into interactions with the environments they pass through and those 
in which they become trapped, as well as the places where they may eventually find safety. Our research has involved extended interviews with members of 10 Hazara households, comprising 12 women and three men. ${ }^{1}$

Hazaras are an ethnic group who traditionally lived in Hazarajat, a rural area lying to the west of Kabul city. This part of central Afghanistan encompasses the headwaters of the Helmand River and lies at the western end of the high Hindu Kush (see Map 1). Its best-known places are the agricultural Ghazni Province and the large city of Bamiyan, home of the famed Buddhas dynamited by the Taliban in 2001. Hazaras owned land and farms in Hazarajat as well as participating widely in social networks with non-Hazara Afghanis. The more numerous Afghani populations are Pashtun, to the south, and Tajik, to the north-east, with both of whom tensions have existed, related partly to the Hazaras' Central Asian origins and visible racial differences. Furthermore, there are sectarian differences: most Hazaras are Shia Muslims while the Pashtuns and Tajiks are predominantly Sunni. Such tensions had led some Hazaras to leave Afghanistan decades before the Taliban took power in Afghanistan around 1996. This group had been living in Pakistan, in areas like that around Brewery ${ }^{2}$ Road, a neighbourhood of Quetta (later called 'Hazara Town'), where they owned houses and engaged actively in the broader mercantile and social life of the country. ${ }^{3}$ In the decades before 1996, Pakistan had been more welcoming of Hazaras and it continued to offer security for many years after the Taliban came to power in Afghanistan. Eventually, however, as Taliban and similar influences rose in Pakistan, Hazaras found themselves facing hostility there too.

\footnotetext{
1 We conducted in-depth interviews with members of 10 separate Hazara households, comprising 15 individuals, aged from 16 to 56 . Our community interpreter was a woman, and we organised interviews by word of mouth. Only three interviewees were male. Since arriving in Australia, most have lived in urban areas, but two families live in Wagga Wagga and had travelled to Sydney to visit fellow Hazaras with whom they had become friends either in Indonesian camps or in earlier resettlement locations within Australia. All the names in this paper are pseudonyms, in accordance with participants' decisions and university ethical requirements. The historical analysis of memory undertaken with Hazaras in Australia, like that with other refugees, has largely been conducted with male narrators. See Denise Phillips, 'Wounded Memory of Hazara Refugees from Afghanistan Remembering and Forgetting Persecution', History Australia 8, no. 2 (2011): 177-98, doi.org/10.1080/14490854.2011.11668379; Jane Haggis and Susanne Schech, 'Refugees, settlement processes and citizenship making: An Australian case study', Journal of National Identities, 12, no. 4 (2010): 365-79, doi.org/10.1080/14608944.2010.520972.

2 Pronounced 'Browery' by all the interviewees.

3 Amin Saikal, 'Afghanistan: The Status of the Shi'ite Hazara Minority', Journal of Muslim Minority Affairs 32, no. 1 (2012): 80-7, doi.org/10.1080/13602004.2012.665623.
} 


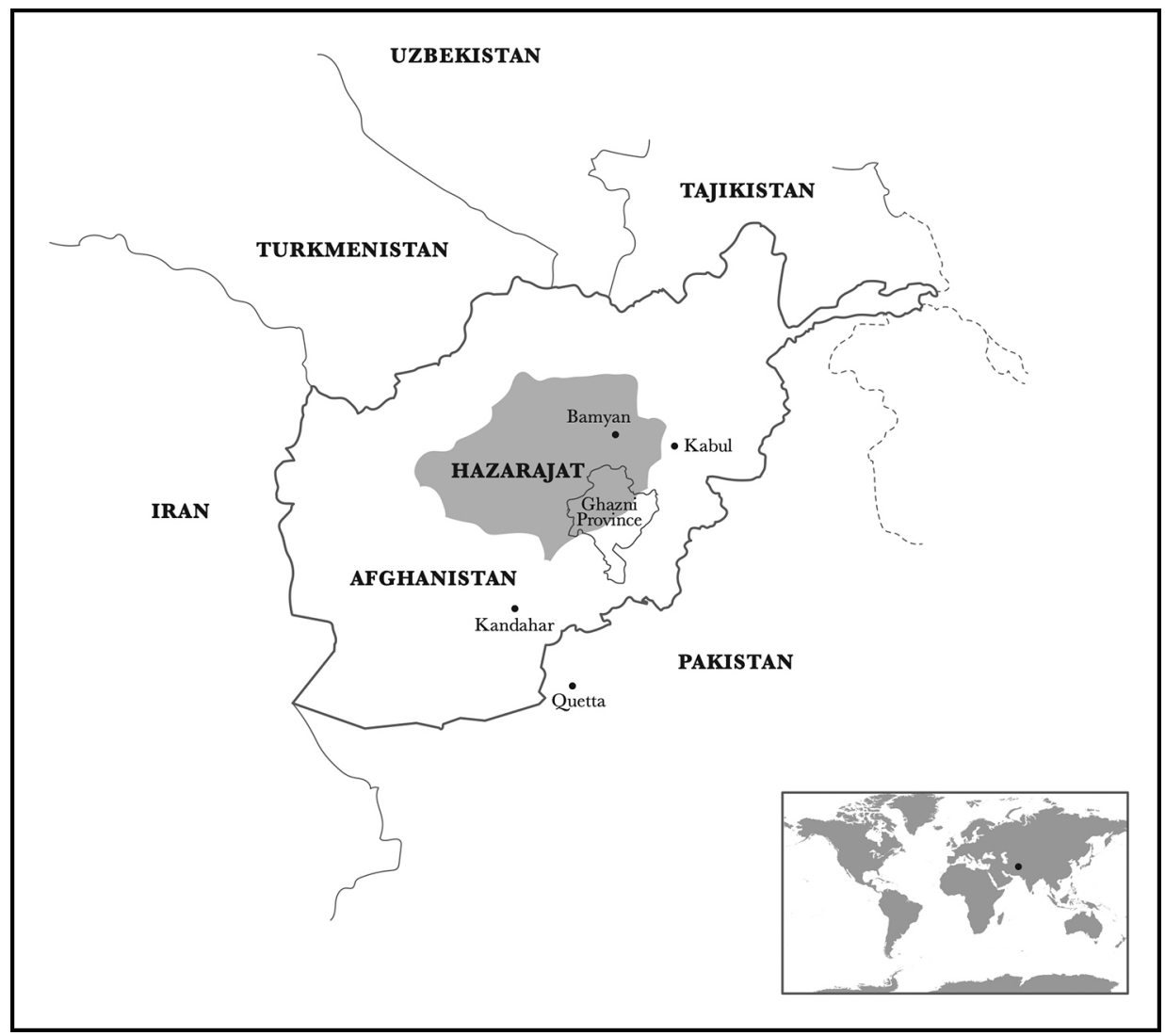

Map 1. Afghanistan, showing the mountainous central region known as Hazarajat and a number of the places in Afghanistan and Pakistan mentioned by our narrators. Inset shows distance between Afghanistan and Australia.

Source: Cartography, Sharon Harrup Design.

Analyses of migrancy and forced migration to (or seeking of asylum in) Australia have been undertaken for many years, although as Ruth Balint and Zora Simic have pointed out, migration studies have recently expanded greatly. ${ }^{4}$ With the influence of international analyses, ${ }^{5}$ attention in Australia has shifted from government policy

4 Ruth Balint and Zora Simic, 'Histories of Migrants and Refugees in Australia', Australian Historical Studies 49, no. 3 (2018): 378-409, doi.org/10.1080/1031461X.2018.1479438.

5 Iain Chambers, Migrancy, Culture, Identity (London: Routledge, 1993); Doreen Massey, Space, Place and Gender (Cambridge: Polity Press, 1994); Doreen Massey, For Space (London: Sage, 2004); Doreen Massey, World City (Cambridge: Polity Press, 2007); Doreen Massey, 'Landscape/space/politics: An essay' (2011), http://thefuture oflandscape.wordpress.com/landscapespacepolitics-an-essay, accessed 12 March 2021; Arjun Appadurai, Modernity At Large: Cultural Dimensions of Globalization (Minneapolis, MN: University of Minnesota Press, 1996); Ben Rogaly, 'Disrupting migration stories: Reading life histories through the lens of mobility and fixity', Environment and Planning D: Society and Space 33 (2015): 528-44. 
to the experiences of migrants themselves. ${ }^{6}$ This global trend has seen many analyses of gender and migration ${ }^{7}$ and, most recently, attention paid to the particularly gendered nature of danger for women in seeking asylum. ${ }^{8}$

The journeys of refugees identified as 'boat people' have been widely publicised in Australia, as have those of many Hazaras. The term originated to describe refugees from Vietnam after 1975, arriving in fishing boats after making a long, island-toisland journey through South-East Asia to northern Australia. More recently, most people attempting to cross the ocean to Australia have been from West Asia and North Africa - the WANA region, including Afghanistan —as the last stage of their long escape. The major Australian political parties have competed to demonstrate their support for the harshest border controls and the least empathy for those excluded. In a number of tragic cases, where boats loaded with refugees have sunk

6 Relevant to this study is Regina Ganter, 'Muslim Australians: The deep histories of contact', Journal of Australian Studies 32, no. 4 (2008): 481-92, doi.org/10.1080/14443050802471384. There are many others, including Margaret Allen, 'Shadow Letters and the "Karnana" Letter: Indians Negotiate the White Australia Policy, 1901-21', Life Writing 8, no. 2 (2011): 187-202, doi.org/10.1080/14484528.2011.559735; Julia Martínez and Adrian Vickers, The Pearl Frontier: Indonesian Labor and Indigenous Encounters in Australia's Northern Trading Network (Honolulu, HI: University of Hawai'i Press, 2015), doi.org/10.1515/9780824854829; Sophie Loy-Wilson, 'Rural Geographies and Chinese Empires: Chinese Shopkeepers and Shop-Life in Australia', Australian Historical Studies 45, no. 3 (2014): 407-24, doi.org/10.1080/1031461X.2014.948020; Sophie Loy-Wilson, Australians in Shanghai: Race, Rights and Nation in Treaty Port China (London: Routledge, 2017), 1-12, doi.org/10.4324/9781315756998; Ian Simpson, "'Decent Fellows, Making an Honest Living": Indian Hawkers in White Australia', History Australia 13, no. 3 (2016): 321-34, doi.org/10.1080/14490854.2016.1202324; Samia Khatun, 'The Book of Marriage: Histories of Muslim Women in Twentieth-Century Australia', Gender \& History 29, no. 1 (2017): 8-30, doi.org/10.1111/14680424.12258; Samia Khatun, Australianama: The South Asian Odyssey in Australia (London: Hurst, 2018), doi.org/ 10.1093/oso/9780190922603.001.0001.

7 Janet H. Momsen, Gender, migration and domestic service (London: Routledge, 1999); Reginald T. Appleyard and Charles W. Stahl, South Pacific migration: New Zealand experience and implications for Australia (Canberra: Australian Agency for International Development, 1995); Nicola Piper, ed., New perspectives on gender and migration: Livelihood, rights and entitlements (New York: UN Research Institute for Social Development and Routledge, 2013); Ruben Gielis, 'A global sense of migrant places: Towards a place perspective in the study of migrant transnationalism', Global Networks 9, no. 2 (2009): 271-87, doi.org/10.1111/j.1471-0374.2009.00254.x; Geraldine Pratt and Brenda Yeoh, 'Transnational (Counter) Topographies', Gender, Place and Culture 10, no. 2 (June 2003): 159-66;, doi.org/10.1080/ 0966369032000079541; Ray Hibbins, 'Migration and gender identity among Chinese skilled male migrants to Australia', Geoforum 36, no. 2 (2005): 167-80, doi.org/10.1016/j.geoforum.2003.10.003; Christina Ho, 'Migration as feminisation? Chinese women's experiences of work and family in Australia', Journal of Ethnic and Migration Studies 32, no. 3 (2006): 497-514, doi.org/10.1080/13691830600555053; Anna Boucher, 'Skill, migration and gender in Australia and Canada: The case of gender-based analysis', Australian Journal of Political Science 42, no. 3 (2007): 383-401, doi.org/10.1080/10361140701513547; J. C. Moya, 'Domestic service in a global perspective: Gender, migration, and ethnic niches', Journal of Ethnic and Migration Studies 33, no. 4 (2007): 559-79, doi.org/10.1080/ 13691830701265420.

8 Ines Keygnaert et al., 'Hidden violence is silent rape: Sexual and gender-based violence in refugees, asylum seekers and undocumented migrants in Belgium and the Netherlands', Culture, Health \& Sexuality 14, no. 5 (May 2012): 505-20, doi.org/10.1080/13691058.2012.671961; R. D. Schweitzer et al., 'Mental health of newly arrived Burmese refugees in Australia: Contributions of pre-migration and post-migration experience', Australian and New Zealand Journal of Psychiatry 45, no. 4 (2011): 299-307, doi.org/10.3109/00048674.2010.543412; UN Women, 'Women refugees and migrants' (2016), www.unwomen.org/en/news/in-focus/women-refugees-andmigrants, accessed 20 November 2018; Ruba Salih, Gender in Transnationalism: Home, Longing and Belonging Among Moroccan Migrant Women (London and New York: Routledge, 2003); Claudia Radel et al., 'Environment, transnational labor migration, and gender: Case studies from southern Yucatán, Mexico and Vermont, USA', Population and Environment 32 (2010): 177-97, doi.org/10.1007/s11111-010-0124-y. 
and lives have been lost, it is the deaths of children and women that have been profiled by the media. ${ }^{9}$ Yet the overwhelming number of 'boat people' to have risked that sea crossing have been men, and the vast majority detained in indefinite onshore and permanent offshore detention (for their perfectly legal attempt to seek asylum) have been men. The non-gendered term 'boat people' has obscured the fact that this is a gendered style of attempting to reach safety in Australia.

Not only is the style of journey very different for Hazara women than it is for Hazara men, beyond this, the circumstances of their journeys sometimes overturn the conventional roles of male and female that shape life in both Afghanistan andonly slightly less rigidly_in Australia.

There has been less discussion to date, however, about the gendered relationships to place and environments for refugees, whether in places of origin, along their pathways of forced mobility, or in their places of settlement. ${ }^{10}$ Work on gender and environment among settled communities in Australia has demonstrated the importance of gender in relationships with the more-than-human world. ${ }^{11}$ There has also been work on the interactions with and meanings of places held by immigrant groups in south-eastern Australia, notably those around urban Sydney ${ }^{12}$ and Wollongong ${ }^{13}$ and in some rural areas. ${ }^{14}$ However, while gender is raised in these studies, it has not been a focus of analysis, nor has the experience of the whole migrant journey been considered. Yet the different roles of men and women at all points during migrancy and in seeking asylum have environmental implications. These differences will all be shaped by the cultures and histories of the people

9 See the loss of the SIEVX, in 2001, at the cost of 352 lives. Beth Gibbings, 'Remembering the SIEV X', The Public Historian 32, no. 1 (2010): 13-30. doi.org/10.1525/tph.2010.32.1.13.

10 Douglas S. Massey et al., 'Environmental change and out-migration: Evidence from Nepal', Population and Environment 32 (2010): 109-36, doi.org/10.1007/s11111-010-0119-8.

11 Vanessa Organo et al., 'Who does the work in sustainable households? A time and gender analysis in New South Wales, Australia', Gender, Place \& Culture 20, no. 5 (2013): 559-77, doi.org/10.1080/0966369X.2012.716401; Chris Gibson et al., 'Climate change and household dynamics: Beyond consumption, unbounding sustainability', Transactions of the Institute of British Geographers 36, no. 1 (2011): 3-8, doi.org/10.1111/j.1475-5661.2010.00403.x; Andrea Gaynor, Harvest of the suburbs: An environmental history of growing food in Australian cities (Crawley: UWA Publishing, 2006); Andrea Gaynor, 'Grappling with "nature” in Australian home gardens 1890-1960', Environment and History 24, no. 1 (2018): 23-38, doi.org/10.3197/096734018X15137949591828; Andrea Gaynor et al., Mallee Country: Land, People, History (Melbourne: Monash University Publishing, 2019).

12 Denis Byrne et al., Place-making in national parks: Ways that Australians of Arabic and Vietnamese background perceive and use the parklands along the Georges River, NSW (Sydney: NSW Office of Environment \& Heritage, 2013); Heather Goodall et al., Waters of belonging: Al-miyahu Tajma'unah. Arabic Australians and the Georges River parklands (Sydney: UTS ePress, 2012), doi.org/10.5130/978-0-9872369-3-7; Allison Cadzow et al., Waterborne: Vietnamese Australians on Sydney's Georges River parks and green spaces (Sydney: UTS ePress, 2011), doi.org/10.5130/978-09924518-1-3; Heather Goodall and Allison Cadzow, Rivers and Resilience: Aboriginal people on Sydney's Georges River (Sydney: UNSW Press, 2009).

13 Gordon Waitt, 'Ethnic diversity, scarcity and drinking water: A provocation to rethink provisioning metropolitan mains water', Australian Geographer 49, no. 2 (2018): 273-90, doi.org/10.1080/00049182.2017.139 4805; Gordon Waitt and Louisa Welland, 'Water, skin and touch: Migrant bathing assemblages', Social \& Cultural Geography 20, no. 1 (2019): 24-42, doi.org/10.1080/14649365.2017.1347271.

14 Natascha Klocker et al., 'Experimenting with agricultural diversity: Migrant knowledge as a resource for climate change adaptation', Journal of Rural Studies 57 (January 2018):13-24, doi.org/10.1016/j.jrurstud.2017.10.006. 
involved, but to contribute to this discussion, we have taken the example of the Hazara experience of material places in their past as well as their hopes and goals for creating relationships to new places.

\section{The 'nature' of water}

This article considers the gendered experience of forced migrancy in relation to water, which in the landlocked Hazara homeland is entirely recognisable as the natural environment. The area is watered by snow-melt streams: Hazaras fish in their waters and all agricultural and household needs are met from streams or the groundwater wells that are linked to them, from which water is carried-usually with great effort and usually by women. Yet even in Hazarajat, water can take many forms - as fresh water it can be rain, snow or ice, as well as a flowing stream or well water, while as salt water it may be the distant ocean or, closer to Hazarajat, it may be a saline water table. In Australia, where we conducted our research with refugee Hazaras, the experience of water is mediated by the economy and infrastructure. So, too, water in the many places along the journeys of these Hazaras has been delivered in various ways and was of widely varying quality. Outside of Hazarajat, the origins of water in the 'natural' environment are harder to see. Yet beyond such physical connections to the more-than-human world, the diversity among human cultures ensures that water, in all these forms, has different meanings.

Sophie Watson, a sociologist who draws on geography and anthropology in her book City Water Matters, has explored cultural practices that express meanings with which water is understood. ${ }^{15}$ One of Watson's detailed examples is particularly relevant to the narratives of the Hazara women we interviewed. This is the religious meaning of water as purification, the state known as tahara. This is the power of water (only occasionally replaced with clean sand if no water is available), which goes beyond its chemical capacity to dissolve or wash away dirt, but instead is understood to bring people closer to their god. Purification is important in a number of daily practices for Muslims, including Hazaras. These practices need to be taught to children and adolescents, a role often considered to be the responsibility of mothers or other women. Two forms of ritual purification - undertaken by both men and women-are understood in this way. One is ghusl, an Arabic term meaning full body washing after particular activities, always shaped by gender, such as sexual intercourse (including ejaculation) or after menstruation. The other is wudu,

15 Sophie Watson, City Water Matters: Cultures, Practices and Entanglements of Urban Water (London: Palgrave Macmillan, 2018), 171, doi.org/10.1007/978-981-13-7892-8. 
the ritualised washing of parts of the body - in a particular order-before prayer, which is required a number of times each day for observant Muslims - five times for Sunni Muslims and three times for Shia Muslims. ${ }^{16}$

Water used for either wudu or ghusl in Hazarajat was drawn directly from the streams and was unquestionably 'natural' - yet in urban areas, including particularly those of developed Australia - this water, from a tap or pipe, may not appear to be part of any natural 'environment' at all. Yet it is imbued with the same cultural meaning for the religiously observant-linking it to a deity and to the more-than-human world created by that deity. Other Abrahamic religions observe different practices with water that are nevertheless each aimed at purifying and linking the individual to their god-including mikvah in Judaism, infant baptism by sprinkled droplets of water in Christianity, and baptism by frequent full-body immersion among Mandaeans, preferably in flowing freshwater rivers but, if necessary, in a small, man-made pool. ${ }^{17}$ A related practice involving both cleansing and purifying is the use of water to clean the anus after defaecation. This is a widely used method of physical and spiritual purification among many religious groups across South Asia, including Hindus and Buddhists. None of our interviewees believed toilet paper to be an effective or 'clean' way to care for the body after defaecation-they had been taught to use water to wash their anus and the surrounding skin in order to be completely clean. In Islam, the use of water to clean the body after going to the toilet was spoken about in terms of a religious obligation as well as hygiene, although $w u d u$ was required afterwards as well to be pure enough for prayer. ${ }^{18}$

Hazara narrators' accounts of their journeys from Hazarajat to Australia often included accounts about water, but sometimes they spoke about it in what would be considered to be 'natural' environments, such as rivers or oceans, while in others they have spoken about water in household or ritual use. The start and finish of these Hazara journeys - from Hazarajat to the Parramatta River in Sydney or the Murrumbidgee in Wagga Wagga — can be considered to be moving from one 'natural' environment to another. Yet the question of water has been raised at many points in the stories about these journeys, not only around identifiably 'natural' environments; it has been the flowing, cleansing and culturally purifying qualities of water, whether it came via a stream or a tap, which have mattered to these narrators.

\footnotetext{
16 Ibid., 170-81. Watson notes that $w u d u$ is also sometimes spelt as $w u d h u$, and she refers to $g h u s l$ (as it is known in Australia) as gushi.

17 Goodall et al., Waters of Belonging. Mandaeans are an Abrahamic religious group whose members follow John the Baptist in practising full-body immersion and doing so frequently. Mandaeans migrated from Palestine across the Middle East, with many settling in Iraq. After persecution there, many sought asylum in Australia, currently living in large numbers on the Georges and Parramatta rivers, in areas adjacent to the Hazaras interviewed in this study.

18 As taught to young girls by the Muslim Women Association in Lakemba, Sydney. Author observation; M. Al-Zoubi et al., 'WASH in Islam-Guide on Water, Sanitation and Hygiene (WASH) from an Islamic Perspective' (Sustainable Sanitation Alliance) (Amman: Deutsche Gesellschaft für Internationale Zusammenarbeit and Sanitation for Millions Jordan, 2020), www.susana.org/en/knowledge-hub/resources-and-publications/library/ details/3958, accessed 27 November 2020.
} 


\section{Home, water and place}

While water has been a frequent component of all the Hazara interviews recorded about forced migration, the most strongly expressed and emotional memory for interviewees was not about water. Instead, when Hazaras told us how they felt about places they had been forced to leave, they often used the English word 'home'. This is an important but elusive concept. For many of the women who were interviewed, such 'home' places had been lost-either they could never return because they were too dangerous, or warfare had damaged and destroyed their homes irretrievably. Such grief for lost places is the substance of much of Peter Read's work in Australia, in which he has recorded the memories and the mourning of Indigenous people and many others for the places they loved. ${ }^{19}$ We have traced the ways that Hazara women interviewees have remembered the places they called 'home'- the places they continue to mourn-and we consider how water has been woven into their stories about loved places.

Sean Field has described the way displaced people in Cape Town, South Africa, during apartheid, have recalled the details of places they were forced to leave. Their memories were often fragmented and partial. Field argues that these displaced people had developed 'frames' to shape their memories, and 'home' was an important frame, giving coherence and explanatory power to what might otherwise have been disconnected glimpses of the places about which they felt so strongly. ${ }^{20}$ This concept of 'home' as a 'frame' has been a helpful way to understand how the Hazara women we interviewed could describe very different experiences of the farming lands around Ghazni and still name them-just as warmly_as their 'home'.

Yet bell hooks has written about quite a different way to understand 'homeplace'as a 'site of resistance'. ${ }^{21}$ She has described how enslaved women in the United States would try to make 'homeplaces' safe and empowering places in which their families — and in particular their children - could experience love and security. These were not the home places of 'cleanliness, comfort and convenience' that Elizabeth Shove explains developed with the economy and technology of the late twentiethcentury Western world. ${ }^{22}$ Instead, they were the insecure and impoverished shacks of nineteenth-century slaves; yet hooks argues persuasively that many enslaved women made great sacrifices to do the cultural work needed so that their families could resist the hostility they faced every day outside in the world of slavery.

19 As Peter Read has discussed in his book, Returning to Nothing: The Meaning of Lost Places (Cambridge: Cambridge University Press, 1996), doi.org/10.1017/CBO9781139085069.

20 Sean Field, ed., Oral History, Community and Displacement: Imagining Memories in Post-Apartheid South Africa. (London: Palgrave Macmillan, 2012), doi.org/10.1057/9781137011480.

21 bell hooks, 'Homeplace (a site of resistance)', in Yearning: Race, Gender and Cultural Politics, ed. bell hooks (Boston, MA: South End Press, 1990), 41-9.

22 Elizabeth Shove, Comfort, Cleanliness + Convenience: The Social Organisation of Normality (Oxford: Berg, 2003). 
This concept_ - of 'making' a 'homeplace' as a 'site of resistance'—offers important clues to the ways the Hazara women interviewed for this project have described their lives in the ghettos of Quetta and other Pakistani cities in which they waited out the long years of exile in hostile physical and social environments before their families could come to Australia. ${ }^{23}$ This approach may also offer insights into the strategies Hazara women employ today in Indonesian camps, despite being trapped there by Australia's closed borders. And, finally, it may be usefully applied to conditions in Australia, where continuing insecurity of residence, poverty of resources, and persisting distrust of authorities may make it impossible to make changes to rented houses or gardens - but where it may still be possible to build a site of emotional and cultural resistance.

\section{Ruptures}

As the Hazara women interviewees told their life histories, it became clear that their arrival in Australia (for most after 2005) had not been the greatest rupture in their lives. There had been surprises, but they often found Australia had few differences from the urban conditions they had had to live in, often for some years. Instead, for most, the greatest rupture had been the forced abandonment of their farms and all their belongings in 1996 when they fled in fear from Taliban attack to the nearby mountains and then to the ghettos of Pakistan. Their arrival in Australia was a small event compared to that earlier trauma.

Mrs Poladi, a Hazara woman born in 1960, was forced to escape from the Taliban with her eight children around 2000, abandoning their farm and all their possessions. Her children were old enough to run along beside her, but she has described the chaotic scenes as people fled for their lives with nothing other than their children's cradles tied to their backs, and their infant children clutched under their arms. One of her sons died in this flight, and she has grieved for him ever since.

Mrs Poladi explained that her farmhouse was important to her because she had laboured on it, investing it with her own identity. She recalled (through an interpreter) that she had spent 'all her younger time, her beauty and her energies to make her home more beautiful by decorating, washing, cleaning, colouring and painting and brushing, mopping'. ${ }^{24}$ She had helped to develop the farm too alongside her husband and family, but she had created the house from her very being. Despite the back-breaking labour needed for this farm, Mrs Poladi remembered an idyllic pastoral life with her family's stock grazing peacefully on the mountainside and their crops picturesquely surrounded by almond trees, fed by fresh steams from springs in

23 See Appadurai, Modernity at Large for an analysis of 'place-making'.

24 Mrs Poladi's interview was conducted in Hazaragi, translated by Latifa Hekmat. 
the mountains. Neighbours co-operated with each other, and there were active social networks between members of various groups, including Pashtuns and Tajiks, with 'unity' between them all as 'Afghanis'. Nothing else in Mrs Poladi's account matches her descriptions of this place, her pleasure in describing its crops and fruiting trees, its clear waters and the rich exchanges between neighbours. As she speaks now of her grief for its loss, she describes it as if it were an unfed orphan, unloved and alone: 'abandoned, dried, not nourished and all of our hard work suddenly lost in war'.

Mrs Poladi did describe conflicts occurring among neighbours over water, but suggested these were later in the period, when the Taliban were rising in power. This time of growing uncertainty was particularly hard for her as a woman-she graphically illustrated how the Taliban insisted that women comply with full head covering, by wrapping her light headscarf tightly over her face and eyes to show me how oppressive she had found it.

This anxious time suddenly turned into open attacks. Mrs Poladi's husband was forced to escape after the first Taliban threats. This took pressure off his family, but left them without the defender on whom they had relied. Attacks escalated until finally Mrs Poladi and her children fled too, scrambling into the mountains to hide in crevasses and caves, fearful of discovery. They spent days eating only grasses and herbs, the fodder for animals. With no utensils, they could drink only the water they could raise to their lips in their cupped hands.

Mrs Poladi's account of the place before her tragic escape is idyllic, but this is not the case with the way Rahima describes farming lands in Hazarajat. Rahima, born in 1993, is much younger than Mrs Poladi, and she describes the farming life from the perspective of a very young girl burdened with the women's heavy work of carrying water from the mountain spring to water the stock, wherever they had been put to pasture on the hills, but then also carrying water down to the family house.

Her tone was bitter as she called herself a 'shepherd', forced to bribe other children to go out with her to pass the time of day while the sheep grazed, before she brought them back to be penned safe from wolves. But her memories of the games they played, the warm summer conditions and clear springs to swim in were almost as idyllic as Mrs Poladi's account of crops and fruit trees. Winters, however, were very different on the hills with the sheep. The waters were frozen and it was hard to make a hole big enough to draw water, let along carry it in the cold to the stock and down to the house. Yet Rahima, just as much as Mrs Poladi, talked about Hazarajat as 'home'. 
Rahima escaped with her family in the early 2000s and was not finally sponsored by the United Nations to come to Australia until 2014. She was granted permanent residency and has since then travelled back from Sydney to Pakistan to visit her family, but, as she explained, she had not ever gone 'home', nor did she feel that the house she shared in Newcastle was 'home'.

Mrs Poladi's memories of Hazarajat as an Arcadian farming land, and even Rahima's memories of winters with grazing stock, tell us little about the actual state of this area. Any atlas shows it to be a rocky, barren area. The Hazaras had been pushed into it by Pashtun and Tajik hostility. But even for the women like Rahima who recall the drudgery of water-carrying and shepherding, Hazarajat is warmly remembered as 'home'. Despite their very different fragments of memories, for both Rahima and Mrs Poladi, Hazarajat remains a place of predictability and stability, even if it were not always comfortable. Their memories tell us little of environmental 'fact' but reveal a great deal about how they felt about this place. Alessandro Portelli has argued persuasively that, in this way, oral history and memory open insights into the past that are not available in any other way. ${ }^{25}$

Water is a key environmental element of each of these women's memories. Whether it is the clear waters of farm or the icy mountain streams of escape for Mrs Poladi, it is clean and flowing water. It was everyday hard work for Rahima, but nevertheless the water she laboured to draw and carry was clean and essential for stock and family. Yet water also carried a powerful message of fear.

\section{Water and danger}

When Rahima and her family escaped with two related families, trying to get into Pakistan, they headed south for Quetta, so they had to pass through Kandahar. Yet after 1996, Kandahar was the headquarters of the new Taliban authority controlling all of Afghanistan. It was difficult to avoid because it lay on the major road leading to Pakistan, so passing through there meant risking the checkpoints manned by young hotheads bristling with weapons. The families were particularly concerned because the Taliban were believed to rape young women, and they were most anxious to hide their daughters. The young girls of the three families were pressed down underneath a blanket between the legs of Rahima's uncle and other relations sitting in the back seat of their vehicle. The girls were not even allowed to raise the blanket to see what was happening. But they could hear every word, which was perhaps even more terrifying. And they were thirsty! For Rahima, the girls seemed to be trapped there for hours in the heat as the young Talibs tongue-lashed and physically slapped her

25 Alessandro Portelli, 'The Death of Luigi Trastulli: Memory and the Event', in The Death of Luigi Trastulli and Other Stories: Form and Meaning in Oral History (Albany, NY: State University of New York, 1991), 1-29. 
relations. Despite being humiliated, they never revealed the presence of the girls. Rahima was terrified - and as a 10-year-old, her thirst amplified her fears, leading her ever since to associate thirst with danger.

These two escape narratives played out very differently in terms of the gender order in which both Mrs Poladi and Rahima were embedded in Hazarajat. Rahima's story points to the sexual vulnerability of refugees, which is widely documented. While sexual violence does have an impact on men and boys during warfare, it is more commonly the case that women suffer sexual vulnerability, sexual attack and sexual exploitation during escapes and in transit camps. ${ }^{26}$ While Rahima's ordeal was terrifying, her older male relations were able to fulfil the roles they were expected to play by protecting the young women in their families from sexual predation.

Mrs Poladi's experience, on the other hand, disrupted the expected gender orderas it did for many women and families who felt abandoned by husbands and fathers who had been forced to flee earlier. Mrs Poladi's husband had been forced to leave her and the children alone. They had no idea where he was or even whether he was alive or dead. Mrs Poladi had lived all her life with the expectation that her husband would fulfil the role of provider and protector. But his absence meant she was absolutely alone when she and her children had to make a desperate escape from their home. In this terrifying flight into the mountains, she had to make all the decisions - and to carry all the tragedy after the loss of her son. Then when they finally reached Quetta, it was Mrs Poladi who had to work out how to provide for her remaining children.

This story was repeated by virtually all the women to whom we spoke. Some families decided against the terrifyingly real dangers of Kandahar and instead paid exorbitant sums to people smugglers to get them across the border via other locations. Once they had crossed the border, some families found temporary shelter in Karachi or Islamabad, but many settled in Quetta, nearer the border. But wherever they were, they then had to make agonising decisions about how to proceed—and the fear of gendered vulnerabilities ensured that it was invariably husbands, fathers or sons who made those long, perilous journeys onwards to try to find a safer place to which their families could escape.

For the public in Australia, it is the men's journeys that are better known. They faced first a difficult journey on foot or by boat, needing to pay smugglers all the way and moving through a series of transit camps, to get to Malaysia. Then they travelled south through Sumatra to the Sunda Strait, between Sumatra and Java. From there, after more waiting time in transit camps and paying more people to source boats, these refugees became 'boat people', paying exorbitant fees to board what were often fragile fishing boats and then setting south, across the eastern Indian Ocean,

26 Keygnaert et al., 'Hidden violence is silent rape'. 
heading for Christmas Island, known to be Australian territory, or, much further, to the Australian mainland itself. In these fearful journeys, water is crucial for asylum seekers in two ways. First there is thirst: there is so little room on these overcrowded boats that food and drinking water are rarely adequate. Then the refugees have to cope with the dangerous waters of the sea itself-even though Christmas Island is close to Indonesia, the waters around it are treacherous, challenging even experienced seafarers in serviceable craft—and these refugees seldom have either of those benefits. If they make it to Australian territory now, they are rapidly shipped offshore to indefinite detention. A decade ago, these men would face detention in mainland Australia, but were eventually able to seek protection visas and, perhaps, bring their family out to be with them.

Australians know little about the lives of the women and children for whom these men were risking their lives to seek safety. It is in those Pakistani cities of first refuge, like Quetta, that women and children were left behind in what seemed like relative safety compared to the dangerous sea crossings. There, in the ghettos, they struggled on alone to keep their children alive and get them educated. They were often stranded there for years - some of the women we spoke to had been 13, 15 or even 20 years in Pakistan - most with very little idea of whether their husbands, fathers or sons were safe, or even where they were. Each of these women described cities where Hazaras were crowded into what had become a tightly packed slum, living on top of each other, sometimes in rented rooms in the houses of more established Hazara owners, and at other times sharing rooms with a number of families in order at least to find shelter. Yet they had nowhere else to go.

In Quetta, Mrs Poladi struggled to keep her family together and safe, to create a 'homeplace', driving herself to make a living by endless sewing. She made clothes on a treadle machine and then spun yarn for the rest of her waking hours to try to raise enough money to feed them all and to get them as much schooling as possible. Her children remember her ceaseless work to bring in enough cash for them to survive.

\section{'Homes' lost to the past}

Yet there were other Hazara experiences. For Elaha, Pakistan had been a very different place. Elaha had been born in 1993, like Rahima, but in Quetta because her family had already been there for decades. It was Pakistan that Elaha called 'home'. She described a place of great freedom, where she and her friends travelled across the city to go to school and had felt comfortable wherever they went. Even as young children, she remembered a sense of belonging and confidence in moving around the city. This had begun to change in her lifetime. By the time she was in senior high school, Quetta had closed down for Hazaras, because of rising hostility from Pakistanis. So instead of feeling comfortable everywhere, she could now only 
move around safely and easily inside the areas around Brewery Road, which had become little more than a ghetto for Hazaras. It is not clear from her memories when this occurred, and whether she felt it was a result of the influx of escaping Hazaras causing an increasing resentment of refugees, or whether it reflected rising Taliban power and intolerance inside Pakistan.

Elaha remembers Pakistan turning against Hazaras and, as a result, her world shrank dramatically to the closed, foetid, overcrowded space of Brewery Road. When, much later, she came to Australia to marry Faiz, whose family had fled from Hazarajat, Elaha was escaping also-not from the Pakistan she had loved and still remembered as 'home', but from today's Pakistan, in which she no longer felt 'at home'.

\section{Exile: Water, home and responsibility}

While for many interviewees, clean water in Hazarajat was central to memories of 'home', water had not been so perfect for all Hazara Afghanis. Some interviewees had lived in Kabul or other large towns and had experienced piped water under government control. Reliable water was only available through these pipes to government employees and those in the buildings in which those officials lived. This type of corruption was familiar from Afghanistan, but when our interviewees reached Pakistan and were forced to take refuge in the overcrowded ghettos, the situation was far worse. This was where they tried to make the 'homeplace' about which hooks has written, to offer not only safety but also resistance to the dehumanisation of war and dispossession. ${ }^{27}$

Water was central to making safe places, in both health and cultural terms. Yet in Pakistan, they faced centralised, unreliably maintained water systems, so overstretched that supply was irregular. The Hazara women had been aware of corruption existing in Afghanistan, but in Pakistan, as hostility to them rose, they encountered even more intrusive corruption, particularly as the lucrative bottled water trade expanded. Piped water was rationed, flowing only on two or three days each week. In drought periods, even this water did not flow, and large sums of money had to be paid to get water delivered from tankers. Back in Hazarajat, women had had to carry water by bucket from often distant wells, yet they remember it fondly in comparison to the water supply in Quetta, which they say was intermittent, unreliable and inadequate. Even worse was the bacterial contamination of government water sources-whether piped or in tankers-it all had to be boiled before drinking. This impacted most heavily on Hazara women - they were the ones struggling to make these 'homeplaces' for their children in the uncertain and overcrowded temporary refuges in which they were waiting till they could move to somewhere safer.

27 hooks, 'Homeplace'. 
Nevertheless, there was much more stability in another dimension of women's experiences in making such 'homeplaces' for their ruptured families in these ghettos. Hazaras, as Shias, shared common practices with Sunni Pakistanis in using water for religious purposes to purify the inner person. As a result, ghusl and wudu could be sustained, allowing these stranded women to feel they were continuing to teach a strong cultural identity and practice to their families.

Such symbolic uses of water were a recurrent theme for each interviewee, and it was clear that, despite the problems with contamination and irregularity of supply in Pakistan, it was still possible to maintain many such religious practices involving the use of water. The women struggling to maintain an income, like Mrs Poladi, were still able to fulfil the role they saw for themselves of making a 'homeplace' for their children by teaching them about the correct ways to use water. But this was to change when they finally came to Australia.

\section{Migrating}

Mrs Poladi and her husband by chance found each other in crowded Quetta. She did not wish to be interviewed about her feelings, but a relation later explained that she had vented her intense anger and bitterness towards her husband, an outpouring of all the tragedy and struggle she had had to go through for so many years on her own. Before the family left Quetta, however, there had been some reconciliation, and now, from Sydney, the children stay in regular touch with their father through the internet. Mrs Poladi has passed through all the hurdles to gain permanent residency for herself in Australia, and is now seeking to sponsor her husband to make the journey to Australia.

Among the women we interviewed, few had made the precarious sea journey with the men in their families. These men had eventually been able to claim 'family reunion' visas in Australia, so the women's journeys were rapid, safe and uneventful. ${ }^{28}$ Their initial impressions also were positive-after the insecurity of Quetta, Karachi or Islamabad, it was a relief to many simply to be in a more stable place, no longer facing hostility and danger.

The women all mentioned the extraordinary experience of being able to roam the area around their new homes at will, of being comfortable anywhere. None were particularly interested in seeking out any pleasant places, but instead talked about the enjoyment of the lack of constraint, of spaciousness. Immigrants from the WANA area who have lived longer in Australia have talked elsewhere about an awareness of racism and of the rising Islamophobia in Sydney, which had increasingly

28 Eerily like the magic realist transition from the homeland to London, about which Mohsin Hamid writes in his novel Exit West (New York: Riverhead, 2017). 
constrained their movements. ${ }^{29}$ The Hazara interviewees, far more recently arrived, felt no such discomfort yet, and instead, particularly among women, talked with surprise and enjoyment of a freedom of movement. For those like Elaha, from Hazara families long established in Pakistan, this recalled their earlier life there, which they remembered as enjoyable because it was more 'modern' than Afghanistan, but which had now been lost to them. For the Afghani Hazaras, the freedom of movement that women were experiencing in Sydney was new and welcomed.

Yet, as Doreen Massey has pointed out, places are nodes in networks of meaning. ${ }^{30}$ These Hazara women made clear the affinity they sustained to the places they remembered. In one example, Hazara residents have created a new name for Auburn Park in western Sydney, which they call Ajia Park. In Hazaragi, Ajia means a place in which older Afghan Hazara women gather to pass the time. Local Hazara residents now refer to Auburn Park among themselves with this new name because it suits their practices, recalling places in their homeland. Offering a reassuring sense of peace of mind and confidence, such renamings are occurring for many different types of places, not only parks but rivers and beaches as well as frequently used buildings like homes and mosques. ${ }^{31}$

Not all Hazaras had been resettled in urban areas. Most refugees had paid so much to people smugglers and other corrupt officials along their journey, that they had few options but to accept whatever resettlement was offered. Even for those originally from rural areas, Australian rural conditions bring little that is familiar. Australian contract harvesting, for example, is very different from the family and community labour on small holdings in Hazarajat. This system disrupted gendered relationships to employment and land even further than the journey had already done.

Water in Australia was problematic too for Hazara women, whether urban or rural. They welcomed finding that water was not rationed but instead flowed constantly, and that you could get hot water without building a fire. They were positive about finding that they did not have to boil water before they drank it as they had had to do in the ghettos. Yet many of the women we interviewed still did boil water becausethey say-it tastes better. The water in Australia tastes 'like chemicals'. Hazara women said it reminded them of the taste of rusty pipes in Quetta, despite being told that the taste in Australia came from chemicals understood to be beneficial, such as fluoride. After so many years living in hostile exile in urban ghettos, these women deeply distrust the government agencies that provide water. Some do not believe, for example, that desalinated water is not recycled sewage. Keeping families safe in this situation poses challenges for them, and is one of the reasons they keep on boiling water.

29 Byrne et al., Placemaking.

30 Massey, 'A Global Sense of Place', chapter 6 of Space, Place and Gender.

31 Latifa Hekmat, participant observation in Auburn, west Sydney. 
This distrust and insecurity is not surprising. Most Hazaras in Sydney still have only uncertain visas, and little income, so they need to live in rented housesand a city like Sydney is high cost. ${ }^{32}$ One problem is the plumbing in Australian bathrooms: there are generally no taps close to toilets nor are there usually handheld bidet 'bum sprayers' (shattaf in Arabic) that allow water to be accessible for anal cleansing. Renting homes for many years, Hazara settlers find that landlords are reluctant to allow alterations to bathroom plumbing to make living more culturally and religiously appropriate. Some women have rigged up soft hoses to allow water to be drawn from the cistern for cleansing, although most use the traditional small spouted jug, widely known as a lota or bodna.

Cooking is a further area of difference and challenge. In Wagga Wagga, one Hazara family_led by the father-has built a small hothouse, to grow the herbs that might make food taste more like home. This too requires water, and is a joint strategy in which both the wife and husband can participate together, in ways not needed in Hazarajat, to create meals that, as the wife explained, will be 'good for remembering' about life 'at home'.

\section{A grievable place}

For some-like Mrs Poladi-there is a continuing desire to find ways in their new homes to express their feelings for their old homes. The grief about those unwatered fields, created with so much labour but now left dry and unnourished, is matched by grief for the lost homes, made and cleaned with so much work (work by women, using water). Mrs Poladi recalls returning home for a visit when her Australian residency was finally secure:

After a long time, I went [home] and when I saw it, I remembered that I used to clean and paint the walls and decorate it with my embroidered curtains. Now those walls are collapsed [and] not there any more. Nothing remained as before. Everything ruined. It made me cry and I couldn't sleep.

There has been little space in Australia to grieve for the powerful imaginaries of the homes that have been lost. This is cultural work, like Arjun Appadurai's 'making places', which is crucial in sustaining social and affective links between people and the places they respect and care for. The need to grieve, to mourn for the lost places, and to be acknowledged and respected as someone who is in mourning, is to offer a process of building identities around new places.

32 In the present day, Hazaras are still being threatened by federal government immigration policies with deportation—called 'repatriation'-to Afghanistan. ABC RN Breakfast, 26 November 2018, www.abc.net.au/ radionational/programs/breakfast/hazaras-in-australia-hear-tales-of-murder-and-displacement/10553384, accessed 12 March 2021. Even when Hazaras hold more permanent residency, their past experiences lead them to feel insecure and anxious much of the time. 
Mrs Poladi has described her grieving process as being the way to connect her new home to her old home, which may be lost forever now, but is able to be evoked. She does this by 'talking to water', believing that it listens to her, and takes her pain and grief from her shoulders. This has an important positive role in Mrs Poladi's life, just as the fulfilment of a mourning process, however long or short that grieving might need to be, can be an important contribution to healing and renewing of life.

As translated from the Hazaragi, this is how Mrs Poladi works through her sense of loss, by connecting to God through water. It is the water that allows her to build these imaginative and affective links.

Interviewers: Do you go to parks to go near the water? Is the river important?

SP: I enjoy water. You know, when I go there, I go and talk to water.

Interviewers: About what sorts of things?

SP: Oh ... God is so great that give[s] us this much water that I can see and I can enjoy, you know, we can drink this water, give us life. You know, just going to spiritual talking. I am talking to the water, 'Thank you, God, you know, you have been giving us a lot of things, very important things, it's very clean and make[s] us clean.' So, he have [sic] given us this great things.

Interviewers: Do the rivers here, in Merrylands, Parramatta, do the rivers here remind [you] of rivers at home, or are they different?

SP: In Afghanistan I heard that more than half of the world is water, you know. So when I see the water here, I can remember in Afghanistan we used to have it where the water was very speedy, you know, it was moving water and here it's very static, it just stays. In Afghanistan water is fresh, it was fresh water, but here it's a bit black, you can see different colours. Yeah. Colourful water.

Interviewers: So, it seems very different, but you still feel able to speak to the water here?

SP: It gives me happiness, it gives me peace of mind when I talk to water. ${ }^{33}$

Her words suggest that she is making new senses of belonging with which to analyse mobility and migrancy. In Mrs Poladi's case, she was seeking to reconcile her love of her idealised but lost 'home' in rural Hazarajat with the new Australian rivers through a connection to her god. This might build the emotional bonds that bring her new place into connection with her lost place where she felt she was 'home'.

This is grief that accords respect to the places that have been lost but also opens up ways to build new bonds. There needs to be space for such grief within the policies and practices of land and river management in Australia, which have shown

33 Mrs Poladi's interview transcript, held by the authors. 
little recognition of what immigrants may bring to their engagement with their new homes. ${ }^{34}$ Yet the necessity of such mourning has been written about movingly by Judith Butler and Bonnie Honig, who each argue that such mourning holds out the power of hope. ${ }^{35}$ This is just as much the 'place making' about which Appadurai writes as the pleasurable family gatherings and picnics recognised as 'making places' and new connections to environments in the places of new homes. ${ }^{36}$ For Mrs Poladi, it has been the complex emotional and spiritual relationship she has with water which offers hope to rebuild a sense of being 'at home'.

\section{Reflections in water and memory}

Oral history and memory have been important tools in learning about the experiences of forced migration. Yet the dangerous circumstances into which asylum seekers are forced as they cross borders to find safety are shaped at every point by the different vulnerabilities of men and women. For those Hazaras who do find safety in Australia, these journeys have been very long-often separating families over years or even decades, with little communication possible and vastly different experiences for all involved. Consequently, the memories of conditions over those years, in different environments, with different resources and different fears, will necessarily vary widely. There is virtually no 'official' record of these journeys, and so studies of refugees who have reached Australia have to be based on oral histories or autobiographies, which, to date for Hazaras, have mostly been about the experiences of men. ${ }^{37}$ Yet as can be seen in the memories of Mrs Poladi and the other Hazara women considered in this article, seeking asylum often meant that men and women in families were separated for many years in different places and had very different experiences. It is essential, therefore, to gather the stories of both women and men who have been through such challenging journeys, simply to learn about how different those experiences might have been. Only then is it possible-but still just as necessary - to consider how gender has differently shaped their memories of 'homeplaces' and of the many environments they experienced, even when together, through those journeys.

\footnotetext{
34 Byrne et al., Placemaking.

35 Judith Butler, 'Violence, Mourning and Politics', Studies in Gender and Sexuality 4, no. 1 (2003): 9-37, doi. org/10.1080/15240650409349213; Judith Butler, Precarious Life: The powers of mourning and violence (London: Verso, 2006); Bonnie Honig, 'Ruth, the model émigré: Mourning and symbolic politics and immigration', in Cosmopolitics: Thinking and Feeling Beyond the Nation, ed. Phen Cheah and Bruce Robbins (Minneapolis, MN: University of Minnesota Press, 1998), 192-215.

36 Appadurai, Modernity at Large; Byrne et al., Placemaking.

37 With regard to journalism, of the 12 biographies of Hazara refugees written by Abdul Karim Hekmat published in The Saturday Paper from 2014 to 2018, eight were about men and the other four were generalised statistical analyses: www.thesaturdaypaper.com.au/contributor/abdul-karim-hekmat, accessed 5 December 2020. See the previously referenced scholarly analyses: Phillips, 'Wounded Memory'; Haggis and Schech, 'Refugees, settlement processes and citizenship making'.
} 
This text is taken from International Review of Environmental History, Volume 7 , Issue 1, 2021, edited by James Beattie, Ruth Morgan and Margaret Cook, published 2021 by ANU Press, The Australian National University, Canberra, Australia.

doi.org/10.22459/IREH.07.01.2021.05 